\title{
The prevalence of homozygous MTHFR polymorphism(s) in a Turkish university hospital population that necessitated MTHFR polymorphism investigation
}

\author{
Fatma Gumruk1, Gokcen Orgul², Ozlem Akgun Dogan ${ }^{3}$, Atakan Tanacan², Ergun Karaagaoglu4 ${ }^{4}$ Mehmet Sinan Beksac²
}

\begin{abstract}
Background: Methylenetetrahydrofolate reductase (MTHFR) polymorphisms may cause various medical disorders through different mechanisms. We aimed to determine the allelic frequency and the prevalence of homozygous MTHFR polymorphisms in a tertiary university hospital population that necessitated MTHFR polymorphism investigation owing to various reasons.

Methods: Our study consisted of 10449 patients who necessitated MTHFR polymorphism investigation owing to various reasons (coronary artery diseases, thrombotic events, epilepsy, migraine, repeated miscarriages, various obstetric complications) during 2008-2017.

Results: The allelic frequency of MTHFR 677 and MTHFR 1298 mutations were 0.296 and 0.283 respectively. The prevalence of homozygous MTHFR C677T and MTHFR A1298C polymorphisms were $10.2 \%$ and $11.1 \%$, respectively.

Conclusion: MTHFR polymorphisms are more frequent than was expected and one should be cautious when drawing disorder specific conclusions.
\end{abstract}

Keywords: demographic analysis, gene frequency, genetic polymorphism, methylenetetrahydrofolate reductase, Turkey

\section{INTRODUCTION}

Methylenetetrahydrofolate reductase (MTHFR) polymorphisms are reportedly to be associated with coronary artery diseases (CAD), thrombotic events, epilepsy, migraine, repeated miscarriages, and various obstetric complications (1-7).

MTHFR is a critical enzyme which plays a role in folate metabolism and participates in the enzyme pathways associated with DNA methylation (8-10). It converts dietary folate (methylenetetrahydrofolate) to active folate, which is the coenzyme that is required by methionine synthase, together with vitamin $B 12(8,10)$. This pathway is also critical in the methylation of nucleotide/DNA which is important in regular DNA synthesis $(11,12)$.

MTHFR polymorphisms may cause various medical disorders through different mechanisms. One of the mechanisms is hyperhomocysteinemia, which accompanies endothelial injury of vascular structures of different organs $(11,13)$. Homocysteine is an endothelial-toxic amino acid which is metabolized through methylation and trans-sulphuration processes. MTHFR polymorphisms also affect DNA synthesis by various routes, one being impaired DNA methylation and another being the accumulation of dietary folate, which is also a toxic material causing endothelial injury. Methylenetetrahydrofolate is converted to dihydrofolate, which in turn is converted to monohydrofolate. This is subsequently reconverted to methylenetetrahydrofolate for the clearance of MTHFR. During this process, translational autoregulation of thymidylate synthase and dihydrofolate reductase, and uridine monophosphate conversion to thymidine monophosphate is impaired, resulting in the formation of tetrameric DNA and related complications $(10,11)$.

MTHFR polymorphism related pathological conditions necessitate MTHFR polymorphism prevalence studies. However, one must consider the chaotic structure and robustness of these relationship(s) and the frequencies of the related mutations (as well as geographical and ethnic distributions) in order to understand the biological rationale

\footnotetext{
Hacettepe University Faculty of Medicine, Department of Pediatrics, Ankara, Turkey.

2 Hacettepe University Faculty of Medicine, Department of Obstetrics and Gynecology, Ankara, Turkey.

3 Hacettepe University Faculty of Medicine, Department of Genetics, Ankara, Turkey.

${ }^{4}$ Hacettepe University Faculty of Medicine, Department of Biostatistics, Ankara, Turkey.
}

\author{
Correspondence: Gokcen Orgul \\ Hacettepe University Faculty of Medicine, Department of Obstetrics and Gynecology, \\ Division of Perinatology, Ankara, Turkey. \\ E-mail: gokcenorgul@gmail.com
}

Received: 28 Feb 2018, Accepted: 30 Mar 2018

(C) 2018 by the authors; licensee Modestum Ltd., UK. This article is an open access article distributed under the terms and conditions of the Creative Commons Attribution License (http://creativecommons.org/licenses/by/4.0/).

Electronic Journal of General Medicine 
Table 1: The Prevalence of Homozygous MTHFR C677T and A1298C Polymorphisms during 2008 to 2017 (htz: heterozygous, hom: homozygous, MTHFR: methylenetetrahydrofolate reductase)

\begin{tabular}{|c|c|c|c|c|c|c|c|c|c|c|}
\hline Year & $\begin{array}{l}677 \\
\text { htz }\end{array}$ & $\begin{array}{l}677 \\
\text { hom }\end{array}$ & $\begin{array}{c}1298 \\
\text { htz }\end{array}$ & $\begin{array}{l}1298 \\
\text { hom }\end{array}$ & $\begin{array}{l}677 \mathrm{htz} / \\
1298 \mathrm{htz}\end{array}$ & $\begin{array}{c}677 \text { hom/ } \\
\text { htz }\end{array}$ & $\begin{array}{c}677 \text { htz/ } \\
1298 \text { hom }\end{array}$ & $\begin{array}{l}677 \text { hom/ } \\
1298 \text { hom }\end{array}$ & Normal & Total \\
\hline 2008 & 141 & 58 & 136 & 62 & 91 & 1 & 2 & 0 & 53 & 544 \\
\hline 2009 & 496 & 163 & 205 & 106 & 120 & 1 & 4 & 0 & 541 & 1636 \\
\hline 2010 & 421 & 127 & 184 & 113 & 260 & 1 & 3 & 1 & 335 & 1445 \\
\hline 2011 & 277 & 112 & 140 & 113 & 78 & 0 & 2 & 1 & 257 & 980 \\
\hline 2012 & 149 & 75 & 166 & 82 & 159 & 1 & 1 & 0 & 127 & 760 \\
\hline 2013 & 163 & 71 & 187 & 99 & 168 & 1 & 1 & 0 & 98 & 788 \\
\hline 2014 & 202 & 117 & 235 & 144 & 203 & 0 & 4 & 0 & 101 & 1006 \\
\hline 2015 & 254 & 141 & 315 & 201 & 264 & 6 & 4 & 1 & 161 & 1347 \\
\hline 2016 & 246 & 145 & 301 & 179 & 107 & 4 & 3 & 0 & 388 & 1373 \\
\hline 2017 & 118 & 52 & 124 & 58 & 84 & 0 & 0 & 0 & 134 & 570 \\
\hline Total & 2467 & 1061 & 1993 & 1157 & 1534 & 15 & 24 & 3 & 2195 & 10449 \\
\hline
\end{tabular}

Table 2: Allelic frequencies of MTHFR 677 and MTHFR 1298 mutations in a population which is screened for vascular problems and/or thrombosis

\begin{tabular}{cc}
\hline Mutation & Allelic frequency \\
\hline MTHFR 677 & 0.296 \\
\hline MTHFR 1298 & 0.283 \\
\hline
\end{tabular}

behind this "inherited folate metabolism disorder" and have better management protocols $(12,14)$. MTHFR polymorphisms are more frequent than has been expected and caution should be exercised when drawing clinical conclusions (15-17).

This study set out to determine the prevalence of MTHFR (C677T and A1298C) homozygous polymorphism(s) in a specific population that necessitated MTHFR polymorphism investigation due to various reasons.

\section{MATERIALS AND METHODS}

This study consisted of 10449 patients who necessitated MTHFR polymorphism investigation owing to various reasons ( $C A D$, thrombotic events, epilepsy, migraine, repeated miscarriages, various obstetric complications, etc.) during 2008-2017. Hacettepe University Hospital Electronic Registry was used for the retrieval of data. Our hospital is a referral center in the capital city of Turkey that provides multidisciplinary approach, and Ankara is located in Central Anatolia Region. The allelic frequencies of the mutations and the prevalence of homozygous MTHFR C677T and A1298C polymorphisms was determined. We have also analyzed the source of departments from where the laboratory tests were requested in between June 2008 and June 2012.

Data were analyzed using SPSS software program version 23. Qualitative data was presented as percentage and frequency, quantitative data was presented as mean \pm standard deviation and number. The number of heterozygous and homozygous alleles (for both MTHFR 677 and 1298) were divided by the total number of alleles to calculate the allelic frequencies.

\section{RESULTS}

The prevalence of homozygous MTHFR C677T and A1298C polymorphisms are shown in Table 1. The prevalence of homozygous MTHFR C677T and A1298C polymorphisms were 10.3 and 11.3 respectively. Table 2 shows the allelic frequencies of MTHFR 677 and MTHFR 1298 mutations in the study group. The allelic frequencies for MTHFR 677 and MTHFR 1298 were 0.296 and 0.283 respectively.

Table 3 shows the origin of departments from where laboratory tests were requested. The data of 5205 patients in between June 2008 and June 2012 were used for this analysis (because of change at the electronic registry system of Hacettepe University Hospitals) and we have demonstrated that $38 \%$ of the cases were from obstetrics \& gynecology (mainly obstetrics) and perinatology departments due to various reasons such as thrombotic events, bad obstetrical history (previous perinatal "morbidity/mortality", especially recurrent miscarriages) and various obstetric complications (during and after pregnancy). 
Table 3: Departmental distribution for MTHFR testing (June 2008- June 2012)

\begin{tabular}{lcc}
\hline Departments & Number of patients & $\%$ \\
\hline Gynecology-Obstetrics & 1978 & 38 \\
\hline Hematology & 1353 & 26 \\
\hline Neurology & 989 & 19 \\
\hline Others & 885 & 17 \\
\hline Total & 5205 & 100 \\
\hline
\end{tabular}

\section{DISCUSSION}

There are various reports related to the prevalence of MTHFR C677T and A1298C polymorphisms in different study populations in Turkey (18-23). Most of these studies are clinical series on different medical disorders $(22,24-26)$. In this short communication, we have aimed to demonstrate the allelic frequencies and the prevalence of homozygous MTHFR C677T and A1298C polymorphisms in patients that necessitated investigation of these mutations. The aim was to have a brief idea about the role and clinical importance of these two polymorphisms in high-risk patients in terms of biological events in combination with endothelial injury and folate metabolism disorders. In this study, we have shown that the allelic frequencies for MTHFR 677 and MTHFR 1298 were 0.296 and 0.283 respectively. It has been reported that allelic frequency of MTHFR C677T was 0.312 in a healthy Serbian population which was a little bit higher than our study population which was consisted of various risk factors, such as, vascular disorders, thrombotic events, folate metabolism disorders, genetic disorders, repeated miscarriages and obstetric complications (27).

The frequency of MTHFR polymorphisms was reported to vary in different ethnic groups. Studies among healthy populations in Greece, Japan, Lebanon and China, reported homozygous MTHFR C677T to be $17.8 \%, 11.5 \%, 11.0 \%$, and $7.9 \%$, respectively. However, the prevalence of homozygosity in the MTHFR A1298C genotype has not been as well studied as with C677T (28-31). In healthy Turkish populations, the prevalence of homozygosity were reported to vary between $8.8 \%$ and $9.6 \%$ for the C677T allele and $10 \%$ and $13.3 \%$ for the MTHFR A1298C allele $(29,32)$. Increased frequency of MTHFR polymorphisms was reported in patients with CAD, thrombotic events, epilepsy, migraine, repeated miscarriages and various obstetric complications (1-7). In our study, the prevalence of homozygous MTHFR C677T and A 1298 C polymorphisms were $10.2 \%$ and $11.1 \%$, respectively, in a group of patients with various risk factors, namely, vascular disorders, thrombotic events, folate metabolism disorders, genetic disorders, repeated miscarriages and obstetric complications. Surprisingly, our findings are similar to the previous reports published from Turkey, although those studies were carried in healthy populations $(18,19,22,23)$. Thus, the prevalence of these polymorphisms in general Turkish population (may be with regional variations) should most probably be less than what we have demonstrated because our large study population is consisted of patients with various risk factors.

In this study, there were some limitations although it was informative and valuable in daily medical practice. First, study group was consisted of only the patients that necessitated MTHFR polymorphism investigation due to various risk factors in terms of thrombotic events. Second, we could not subclassify the patients in terms of coexisting medical disorders which may influence the results. Finally, it was not possible to claim that our findings indicate the entire Turkish population.

\section{CONCLUSION}

MTHFR polymorphisms are more than just risk factors for folate metabolism disorders and/or thrombotic events but triggers biological mechanisms for various medical/metabolic disorders.

\section{REFERENCES}

1. Harpel PC, Zhang $X$, Borth W. Homocysteine and hemostasis: pathogenetic mechanisms predisposing to thrombosis. The Journal of nutrition. 1996;126(4S):1285S. https://doi.org/10.1093/jn/126.suppl_4.1285S PMid:8642472

2. van Beynum IM, Kapusta $L$, den Heijer M, Vermeulen SH, Kouwenberg M, Daniëls $O$, et al. Maternal MTHFR 677C> $T$ is a risk factor for congenital heart defects: effect modification by periconceptional folate supplementation. European heart journal. 2006;27(8):981-7. https://doi.org/10.1093/eurheartj/ehi815 PMid:16524890 
3. Nurk E, Tell GS, Refsum H, Ueland PM, Vollset SE. Associations between maternal methylenetetrahydrofolate reductase polymorphisms and adverse outcomes of pregnancy: the Hordaland Homocysteine Study. The American journal of medicine. 2004;117(1):26-31. https://doi.org/10.1016/j.amjmed.2004.01.019 PMid:15210385

4. Caccamo D, Condello S, Gorgone G, Crisafulli G, Belcastro V, Gennaro S, et al. Screening for C677T and A1298C MTHFR polymorphisms in patients with epilepsy and risk of hyperhomocysteinemia. Neuromolecular medicine. 2004;6(2-3):117-26. https://doi.org/10.1385/NMM:6:2-3:117

5. Pan X, Wang P, Yin X, Liu X, Li D, Li X, et al. Association between maternal MTHFR polymorphisms and nonsyndromic cleft lip with or without cleft palate in offspring, a meta-analysis based on 15 case-control studies. International journal of fertility \& sterility. 2015;8(4):463. https://doi.org/10.22074/ijfs.2015.4186 PMid:25780529 PMCid:PMC4355933

6. Dean J, Robertson Z, Reid V, Wang Q, Hailey H, Moore S, et al. A high frequency of the MTHFR 677C> T polymorphism in Scottish women with epilepsy: possible role in pathogenesis. Seizure. 2008;17(3):269-75. https://doi.org/10.1016/j.seizure.2007.08.003 PMid:17904392

7. Den Heijer M, Lewington S, Clarke R. Homocysteine, MTHFR and risk of venous thrombosis: a meta-analysis of published epidemiological studies. Journal of Thrombosis and Haemostasis. 2005;3(2):292-9. https://doi.org/10.1111/j.1538-7836.2005.01141.x PMid:15670035

8. Hoffer L. Homocysteine remethylation and trans-sulfuration. Metabolism. 2004;53(11):1480-3. https://doi.org/10.1016/j.metabol.2004.06.003 PMid:15536605

9. Stover PJ. One-carbon metabolism-genome interactions in folate-associated pathologies. The Journal of nutrition. 2009;139(12):2402-5. https://doi.org/10.3945/jn.109.113670 PMid:19812215 PMCid:PMC2777484

10. Turgal M, Yazicioglu A, Ozyuncu O, Beksac M. Impaired DNA methylation leading to heterotrisomy. Journal of Obstetrics and Gynaecology. 2013;33(8):904. https://doi.org/10.3109/01443615.2013.838547 PMid:24219741

11. Castro R, Rivera I, Ravasco $P$, Camilo $M$, Jakobs $C$, Blom H, et al. 5, 10-methylenetetrahydrofolate reductase $($ MTHFR) $677 \mathrm{C} \rightarrow \mathrm{T}$ and $1298 \mathrm{~A} \rightarrow \mathrm{C}$ mutations are associated with DNA hypomethylation. Journal of medical genetics. 2004;41(6):454-8. https://doi.org/10.1136/jmg.2003.017244 PMid:15173232 PMCid:PMC1735802

12. Şahin TG, Şahin N, Besler T, Beksaç S. Methionine Restricted Diet; Clinical Application. Gynecology Obstetrics \& Reproductive Medicine. 2012;18(1):54-61.

13. Solanky N, Jimenez AR, D'Souza S, Sibley C, Glazier J. Expression of folate transporters in human placenta and $\begin{array}{llll}\text { implications for homocysteine metabolism. 2010;31(2):134-43. } & \text { Placenta. }\end{array}$ https://doi.org/10.1016/j.placenta.2009.11.017 PMid:20036773

14. Kosar A, Kasapoglu B, Kalyoncu S, Turan H, Balcik OS, Gümüs El. Treatment of adverse perinatal outcome in inherited thrombophilias: a clinical study. Blood Coagulation \& Fibrinolysis. 2011;22(1):14-8. https://doi.org/10.1097/MBC.0b013e32834013f2 PMid:21042205

15. Lykke J, Bare L, Olsen J, Lagier R, Arellano A, Tong C, et al. Thrombophilias and adverse pregnancy outcomes: results from the Danish National Birth Cohort. Journal of Thrombosis and Haemostasis. 2012;10(7):1320-5. https://doi.org/10.1111/j.1538-7836.2012.04773.x PMid:22578003

16. McEwen BJ. Methylenetetrahydrofolate Reductase (MTHFR): mythology or polymorphism (ology)? Advances in Integrative Medicine. 2016;3(3):79-81. https://doi.org/10.1016/j.aimed.2017.02.005

17. Perez ABA, D'Almeida V, Vergani N, de Oliveira AC, de Lima FT, Brunoni D. Methylenetetrahydrofolate reductase (MTHFR): incidence of mutations C677T and A1298C in Brazilian population and its correlation with plasma homocysteine levels in spina bifida. American Journal of Medical Genetics Part A. 2003;119(1):20-5. https://doi.org/10.1002/ajmg.a.10059 PMid:12707953

18. Sazci A, Ergul E, Kaya G, Kara I. Genotype and allele frequencies of the polymorphic methylenetetrahydrofolate reductase gene in Turkey. Cell biochemistry and function. 2005;23(1):51-4. https://doi.org/10.1002/cbf.1132 PMid:15386535

19. Ozarda Y, Sucu DK, Hizli B, Aslan D. Rate of T alleles and TT genotype at MTHFR 677C-> T locus or C alleles and CC genotype at MTHFR 1298A-> C locus among healthy subjects in Turkey: impact on homocysteine and folic acid status and reference intervals. Cell biochemistry and function. 2009;27(8):568-77. https://doi.org/10.1002/cbf.1610 PMid:19764044

20. Uçar F, Sönmez M, Ovalı E, Özmenoǧlu M, Kartı SS, Yılmaz M, et al. MTHFR C677T polymorphism and its relation to ischemic stroke in the Black Sea Turkish population. American journal of hematology. 2004;76(1):40-3. https://doi.org/10.1002/ajh.20050 PMid:15114595 
21. Izmirli $M$, Inandiklioglu $N$, Abat $D$, Alptekin $D$, Demirhan $O$, Tansug $Z$, et al. MTHFR gene polymorphisms in bladder cancer in the Turkish population. Asian Pac J Cancer Prev. 2011;12(7):1833-5. PMid:22126575

22. Çetintaş VB, Gündüz C. Association between polymorphism of MTHFR c. 677C> T and risk of cardiovascular disease in Turkish population: a meta-analysis for 2.780 cases and 3.022 controls. Molecular biology reports. 2014;41(1):397-409. https://doi.org/10.1007/s11033-013-2873-z PMid:24264431

23. Caner M, Bircan R, Sevinç D, Benli F, Güney Al, Kurtoglu N. MTHFR, prothrombin and Factor $V$ gene variants in Turkish patients with coronary artery stenosis. Genetics and Molecular Biology. 2008;31(4):836-8. https://doi.org/10.1590/S1415-47572008005000023

24. Yasa MH, Bolaman Z, Yukselen V, Kadikoylu G, Karaoglul A, Batun S. Factor V Leiden G1691A, prothrombin G20210A, and MTHFR C677T mutations in Turkish inflammatory bowel disease patients. Hepatogastroenterology. 2006;54(77):1438-42. PMID:17708272

25. Sener EF, Oztop DB, Ozkul Y. MTHFR gene C677T polymorphism in autism spectrum disorders. Genetics research international. 2014;2014. http://dx.doi.org/10.1155/2014/698574

26. Deligezer U, Akisik EE, Dalay N. Homozygosity at the C677T of the MTHFR gene is associated with increased breast cancer risk in the Turkish population. in vivo. 2005;19(5):889-93.

27. Djordjevic $V$, Rakicevic $L$, Mikovic $D$, Kovac M, Miljic $P$, Radojkovic $D$, et al. Prevalence of factor $V$ leiden, factor $V$ cambridge, factor II G20210A and methylenetetrahydrofolate reductase C677T mutations in healthy and thrombophilic Serbian populations. Acta haematologica. 2004;112(4):227-9. https://doi.org/10.1159/000081280 PMid:15564739

28. Angelopoulou K, Nicolaides A, Constantinou Deltas C. Prevalence of genetic mutations that predispose to thrombophilia in a Greek Cypriot population. Clin Appl Thromb Hemost. 2000;6(2):104-7. https://doi.org/10.1177/107602960000600211 PMid:10775032

29. Sazci A, Ergul E, Kaya G, Kara I. Genotype and allele frequencies of the polymorphic methylenetetrahydrofolate reductase gene in Turkey. Cell Biochem Funct. 2005;23(1):51-4. https://doi.org/10.1002/cbf.1132 PMid:15386535

30. Mao R, Fan Y, Chen F, Sun D, Bai J, Fu S. Methylenetetrahydrofolate reductase gene polymorphisms in 13 Chinese ethnic populations. Cell Biochem Funct. 2008;26(3):352-8. https://doi.org/10.1002/cbf.1450 PMid:18098118

31. Almawi WY, Finan RR, Tamim H, Daccache JL, Irani-Hakime N. Differences in the frequency of the C677T mutation in the methylenetetrahydrofolate reductase (MTHFR) gene among the Lebanese population. Am J Hematol. 2004;76(1):85-7. https://doi.org/10.1002/ajh.20047 PMid:15114606

32. Ekim M, Ekim H, Yilmaz YK. The prevalence of Factor V Leiden, prothrombin G20210A, MTHFR C677T and MTHFR A1298C mutations in healthy Turkish population. Hippokratia. 2015;19(4):309-13. PMid:27688694 PMCid:PMC5033140 